\title{
Inflation and the Size of Government
}

\author{
Song Han and Casey B. Mulligan
}

It is commonly supposed in public and academic discourse that inflation and big government are related. The authors show that economic theory delivers such a prediction only in special cases. As an empirical matter, inflation is significantly positively related to the size of government mainly when periods of war and peace are compared. The authors find a weak positive peacetime timeseries correlation between inflation and the size of government and a negative cross-country correlation of inflation with non-defense spending. (JEL E52, E61, E63)

Federal Reserve Bank of St. Louis Review, May/June 2008, 90(3, Part 2), pp. 245-67.

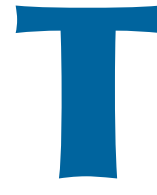

raditionally, economic reasoning has been used to explain the reactions of consumers and firms to government policies. There is now growing appreciation that economic reasoning can explain government behavior as well. Can such reasoning explain which countries inflate and when? Alesina and Summers (1993), Cukierman (1992), and many others have recently begun to try to make such predictions.

Although we have relatively little to add to the literature on positive theories of inflation, we believe that one correlation in particular is especially relevant for such theories: the correlation between inflation and the size of government. With much being said in the literature on the theory of inflation, it is important to see how the theoretical predictions match the empirical evidence. Such evidence is provided in this paper. We study, from a public-finance perspective, how inflation varies across countries and over time in response to the changes in the size of government.

In particular, we first discuss how the quantity of government spending fits into the normative theories of inflation and public finance both in static models and in the steady states of dynamic models. These normative theories-following Barro (1979), Judd (1989), and others-might also be used as positive theories of long-run inflation. The lessons we learn from these studies are that, on the one hand, the conventional optimal tax considerations have suggested that the optimal inflation tax should increase with government spending (e.g., Mankiw, 1987, Veigh, 1989, and Poterba and Rotemberg, 1990); on the other hand, it has also been shown that, when money is a certain type of "intermediate good," it is not necessarily optimal for bigger governments to inflate more (e.g., Kimbrough, 1986, Woodford, 1990, and Correia and Teles, 1996).

We also review the dynamic stochastic theories of public finance in which governments optimally inflate and deflate in response to surprises caused by government spending shocks and economic conditions. These models emphasize the unanticipated portion of government spending and seem particularly applicable to times of war

Song Han is a senior economist at the Board of Governors of the Federal Reserve System. Casey B. Mulligan is a professor of economics at the University of Chicago. The authors thank Darrel Cohen, John Conlon, Lars P. Hansen, Chris Haynes, Nellie Liang, Robert Lucas, Alvario J. B. do Nascimento, William Shugart, and the participants of workshops at the University of Chicago, the University of Mississippi, SUNY-Buffalo, and the FMA European Conference for their comments.

(c) 2008, The Federal Reserve Bank of St. Louis. The views expressed in this article are those of the author(s) and do not necessarily reflect the views of the Federal Reserve System, the Board of Governors, or the regional Federal Reserve Banks. Articles may be reprinted, reproduced, published, distributed, displayed, and transmitted in their entirety if copyright notice, author name(s), and full citation are included. Abstracts, synopses, and other derivative works may be made only with prior written permission of the Federal Reserve Bank of St. Louis. 


\section{Han and Mulligan}

(e.g., Barro and Gordon, 1983a, and Lucas and Stokey, 1983).

Our empirical analysis makes three contributions to the literature. First, we use three dimensions of data-cross-country, time-series, and wartime-to study how inflation responds to government spending, whereas previous studies mainly looked at cross-country evidence (e.g., Campillo and Miron, 1997, and Click, 1998). The cross-country analysis is most suitable to study the long-run relation between inflation and the size of government-or, in other words, how inflation responds to permanent changes in the size of government. To study how inflation responds to temporary changes in the size of government, time-series analysis is more appropriate. The wartime analysis provides evidence of what happens to inflation when the temporary changes in government spending are large. In particular, we study the behavior of inflation during suspensions of convertibility in the classical gold-standard periods and in the paper-standard periods.

Second, we study how inflation responds to the changes in not only total government spending but also its components, defense and non-defense spending. Distinguishing between defense and non-defense spending is necessary because most of the large temporary changes in the size of government are due to changes in defense spending in wartime, whereas other increases in the size of government are mainly due to the secular increases in non-defense spending. Also, changes in defense spending are more likely to be exogenous than changes in non-defense spending (Becker and Mulligan, 2003). Hence the effects of defense spending on inflation may be different from those of non-defense spending. The previous studies on this topic, such as Campillo and Miron (1997) and Click (1998), did not study how inflation is related to the components of government spending.

Third, we use an instrumental variable (IV) method to mitigate the potential bias caused by the endogeneity of government size and nondefense spending in the ordinary least-squares (OLS) regressions. ${ }^{1}$ The IV we use is the ratio of Social Security spending to output, because, although the ratio of Social Security spending to output is correlated with the ratio of non-Social Security non-defense government spending to output, it is unlikely to be correlated with inflation directly. This independence arises because most countries rely exclusively on payroll taxes to finance Social Security spending. ${ }^{2}$ We will discuss more about the appropriateness of the instrument in the third section. Previous studies did not attempt to correct the possible endogeneity problems in their OLS regressions.

The next section reviews the existing theories of inflation. The third section presents evidence from 80 countries showing that there is little cross-country correlation between inflation and the size of government. Defense spending is slightly positively correlated and non-defense spending slightly negatively correlated with inflation. Thus, although we explicitly recognize that seigniorage enters the government budget constraint, we suggest that the emphasis of Sargent (1982) and others on "inflation as a fiscal phenomenon" is not very useful for predicting inflation across countries. These results are also contrary to previous studies, such as those by Grilli, Masciandaro, and Tabellini (1991) and Campillo and Miron (1997), that found a positive correlation between inflation and the size of government.

The fourth section studies U.S. and U.K. timeseries data on inflation and government spending. We show that inflation and the size of government have both trended upward while the temporary increases in government spending during wartime have also been positively correlated with inflation. The fifth section takes a closer look at wartime inflation during suspensions of convertibility in the classical gold-standard and the paper-standard

\footnotetext{
1 There are several possibilities of why government spending may be endogenous. For example, governments may want to reduce spending or their deficit to reduce inflation. Cukierman (1992) and Becker and Mulligan (1997) also suggest that government spending may respond to inflation and not the other way around (which is discussed in the next session). Finally, governments with limited means for taxing their citizens cannot spend very much and must rely relatively heavily on seigniorage for the little revenue that they do spend.

2 In some countries, such as the United States, Social Security payments are indexed to the changes in the cost of living. However, the ratio of Social Security spending to output may not necessarily change with the cost of living because of the high correlation between the changes in the cost of living and the changes in the gross domestic product (GDP) price deflator.
} 
periods. We show that inflation rises above normal at the beginning of wars, whereas inflation falls below normal at the conclusion of wars except in countries that are defeated.

\section{THEORY}

In this section, we review the normative theories of inflation in public finance that relate inflation to the size of government. The review also provides a guide to our empirical specifications.

\section{Inflation in the Static Theory of Public Finance}

It has been argued by Barro (1979), Judd (1989), and others that the normative theory of public finance can also serve as a positive theory of government policy. Although a literal application of the normative theory absurdly suggests that economies are run by "benevolent social planners," Becker (1983 and 1985), Wittman (1995), and others have shown that in more realistic political models of government decisionmaking, policies reflect efficiency considerations in the long run. For example, Becker's (1983, p. 386) proposition 4 states that "competition among pressure groups favors efficient methods of taxation." Thus we first turn to the normative theory of public finance to obtain a prediction for the relationship between inflation and the size of government.

Following Ramsey (1927), Phelps (1973) argues that, because seigniorage is a source of government revenue, the marginal deadweight loss of inflation should be equated to the marginal deadweight loss of other taxes. Presumably the marginal deadweight loss of other taxes is greater when the government must raise more revenue. So, assuming the relevant portion of the seigniorage Laffer curve is upward sloping, larger governments should have higher inflation rates, more seigniorage, and a greater marginal deadweight loss from inflation.

However, it has been argued by Kimbrough (1986), Woodford (1990), and others that Ramsey's (1927) formulation does not directly apply to the inflation tax because the inflation tax affects the marginal deadweight loss of other taxes. With some configurations of tastes and technologies, the marginal deadweight loss of inflation and that of other taxes can never be equated because a higher inflation rate sufficiently increases the marginal deadweight loss of other taxes such that the Ramsey-optimal "inflation tax rate" is zero. ${ }^{3}$ In many models, an optimal inflation tax rate of zero-often referred to as the "Friedman rule," due to Milton Friedman's (1969) advocacy of such a policy-corresponds to a zero nominal interest rate and an inflation rate equal to zero minus the real interest rate.

Because inflation and nominal interest rates in nearly every country and every year since 1945 have been positive, the Friedman rule can hardly serve as a positive theory of inflation. But can the basic logic of the models of Kimbrough (1986), Woodford (1990), and others deliver a prediction for the relationship between inflation and the size of government? If the reason for deviating from the Friedman rule has to do with reasons of politics or equity, then these models are not up to the task. But, as Woodford (1990), Faig (1988), and others have pointed out, the Ramsey-optimal inflation tax rate is positive for some of these models. Unfortunately, these models are still pretty ambiguous about the relationship between inflation and the size of government. To see this, consider the model of Mulligan and Sala-i-Martin (1997), which they show to be a generalized version of many of the models that have appeared in the literature. In the spirit of the inventory models of demand for money, money reduces the transaction costs, or "shopping time," of purchasing consumption goods rather than entering the consumer's utility function. Utility is therefore defined only over consumption and leisure, $u(c, l)$, a function that is assumed to have the usual properties. Shopping time $v$ is a function of two variables: the amount of transactions and the real money stock held by the consumer. The quantity of transactions is assumed to be equal to $c$ plus a fraction $\lambda$ of consumption tax revenues, $\tau_{C}$ : This allows for the possibility

3 See also Chari, Christiano, and Kehoe (1996), Correia and Teles (1996, 1999), and de Costa and Werning (2007) for situations in which the Friedman rule is optimal. Mulligan and Sala-i-Martin (1997) review the literature and discuss the economics of these results. 
that not all taxes have to be paid with money or that the "velocity" of money used to pay taxes is greater than the velocity of other money. Mulligan and Sala-i-Martin define the indirect utility function, $V(\tau, R)$, according to

$$
V(\tau, R) \equiv \max _{c, l, m} u(c, l)
$$

subject to

$$
R m+(1+\tau) c \leq T-1-v([1+\lambda \tau] c, m),
$$

where $R$ is the nominal interest rate and $T$ is the time endowment. The Ramsey problem is

$$
\max _{\tau, R} V(\tau, R) \text { s.t. } \tau c(\tau, R)+R m(\tau, R) \geq g,
$$

where $g$ is government spending (taken as given in the Ramsey problem) and $c(\tau, R)$ and $m(\tau, R)$ are "demand functions" from the consumer's optimization program.

Within the above framework, Mulligan and Sala-i-Martin showed that how $R$ and $g$ are related depends crucially on the functional forms of the indirect utility function, $V$, and the transaction function, $v$. In particular, their proposition 10 states the following:

If the shopping time function $v(x, m)$ is homogeneous of degree one and the Laffer conditions hold, ${ }^{4}$ then the Ramsey optimal inflation tax depends only on the monetary parameters (the fraction of taxes paid with money, $\lambda$, and the shape of the shopping time function $v(\cdot))$.

(Mulligan and Sala-i-Martin, 1997, p. 704)

That is, although the Ramsey-optimal inflation tax is not necessarily zero, it is independent of the size of government in the special case described by the proposition. Thus we cannot say for sure whether static optimal tax considerations predict a positive relationship between inflation and the size of government. However, Mulligan and Sala-i-Martin's (1997) calibration of the monetary parameters from micro and macro empirical studies of consumer behavior suggest that, when the Laffer conditions hold, the Ramsey-optimal

4 That is, the relevant portion of the seigniorage Laffer curve is upward sloping. inflation tax is quite small and quantitatively insensitive to the size of government.

The Laffer conditions may not hold in some countries. If the maximum amount of revenue that can be raised from the non-inflation taxes (the top of the "non-inflation tax Laffer curve") is less than the required revenue, $g$, then inflation tax revenue must increase in response to increases in $g$. Assuming that the top of the inflation Laffer curve has not yet been reached, then more $g$ means higher inflation. One empirically relevant example may be countries without effective personal income tax systems. These may be the best cases for Sargent's (1982) and others' emphasis on inflation as a fiscal phenomenon.

\section{Inflation as State-Contingent Debt Manager}

Lucas and Stokey (1983), Judd (1989), and others have argued that an optimal tax policy involves the use of "state-contingent debt." Citizens buy contingent claims on the government, which pay off extraordinarily well when government revenues (spending) are above (below) expectations and poorly when government revenues (spending) are below (above) expectations. Judd (1989) argues that nominal government liabilities and nominal provisions in the tax code serve this state-contingent debt function, with monetary policy adjusting the price level appropriately to achieve the right pattern of payoffs for the state-contingent debt. Thus, inflation is above normal upon the receipt of "bad news" about the government's fiscal situation and below normal upon receipt of "good news." One empirical counterpart to good and bad news is the beginning and end of wars-inflation should be high during the war and prices should jump down at the conclusion of the war. ${ }^{5}$

\section{Inflation as Evidence of a Commitment Problem}

Alesina and Tabellini (1987), Barro and Gordon (1983a,b), and others have argued that

\footnotetext{
5 The exact timing of wartime inflation depends on expectations about the duration and cost of the war and how those expectations change over time. The end of a war is, of course, "bad news" to the defeated country, especially when large reparations are expected.
} 
inflation is evidence of a government that cannot make credible promises. Such governments, optimally inflate to enjoy the short-run benefits of price-level surprises. Depending on which types of agents are best represented in the government (e.g., creditors or debtors), either surprise inflation or surprise deflation can provide short-run gains for the government, but it is commonly assumed in the literature that surprise inflation is desirable. In this case, governments inflate more in the absence of commitment. Barro and Gordon derived a formula for the inflation rate chosen by the discretionary government: It is an increasing function of the "full commitment" inflation rate and an increasing function of the benefits of surprise inflation. ${ }^{6}$ In particular, they pointed out that the benefits of surprise inflation include temporary increases in output and decreases in real values of government debts.

If the size of government is uncorrelated with a government's ability to make commitments and with the benefits of surprise inflation, then, because the discretionary inflation rate is an increasing function of the "full commitment" inflation rate, the Barro and Gordon model inherits the predictions of the static public finance model for the relationship between inflation and the size of government. Relatively little is known about a government's ability to make commitments or the benefits of surprise inflation, so we can say little about the correlation between inflation and the size of government in the general case. However, Alesina and Summers (1993) have suggested that governments make commitments by creating an independent central bank. Inflation should therefore be negatively related to central bank independence, and, holding constant independence and the benefits of surprise inflation, inflation should vary with the size of government and other variables as suggested by the static theory of inflation and public finance.

\footnotetext{
6 The Barro-Gordon discretionary government minimizes $a\left(\pi-\pi^{*}\right)^{2} / 2-b\left(\pi-\pi^{\mathbf{e}}\right)$, taking $\pi^{\mathbf{e}}$ as given. $\pi$ is actual inflation (chosen by the government), $\pi^{\mathrm{e}}$ is expected inflation, and $\pi^{*}$ is the "static" or "full commitment" optimal inflation. Because expectations are formed with full knowledge of the government's objective, the equilibrium inflation rate under a discretionary government is $\pi^{\mathrm{e}}=\pi=b / a+\pi^{*}$. Thus, given $b / a, \pi$ varies directly with $\pi^{*}$. Also, $\pi$ increases as the benefit of surprise inflation, $b$, increases.
}

\section{The Size of Government as a Response to Efficient Taxes}

Cukierman (1992) and Becker and Mulligan (2003) argue that the size of the government responds to the efficiency of taxes. A country without access to efficient taxes (perhaps for technological reasons or because those harmed by efficient taxes are politically powerful) will have a smaller government and rely relatively heavily on inefficient taxes (such as inflation) for revenue. Thus, inflation and the size of government can be negatively correlated.

If we further accept the auxiliary hypothesis of Becker and Mulligan (2003) that defense spending is "exogenous" while non-defense spending is "endogenous" (i.e., more sensitive to the efficiency of taxes), then we also expect defense spending to be positively correlated with inflation and non-defense spending to be negatively correlated with inflation.

Because the theory here suggests that government spending, especially non-defense spending, responds to inflation instead of the other way around, the OLS regressions of inflation on government size may be biased. We will discuss how we use instrumental variable (IV) methods to correct the potential bias.

\section{CROSS-COUNTRY EVIDENCE}

The cross-country analysis provides evidence on the long-run or steady-state relation between inflation and the size of government. Our sample consists of 80 countries during the period 197390. Inflation is measured by the average growth rates of the consumer price index (CPI) and M1, and the size of government is measured by the average of the ratios of general government spending to GDP. ${ }^{7}$ Only countries with at least four consecutive years of observations in the period 1973-90 are included in our sample. Figure 1 is

\footnotetext{
7 Data on general government expenditure, defense spending, and GDP are from the International Monetary Fund (IMF) Government Finance Statistics Yearbooks (various years) and supplemented with the United Nations National Accounts Statistics: Main Aggregates and Detailed Tables (various issues). Data on CPI and
} M1 are from the IMF Statistics Yearbook (various years). 


\section{Figure 1}

\section{Inflation and Government Size, 1973 to 1990}

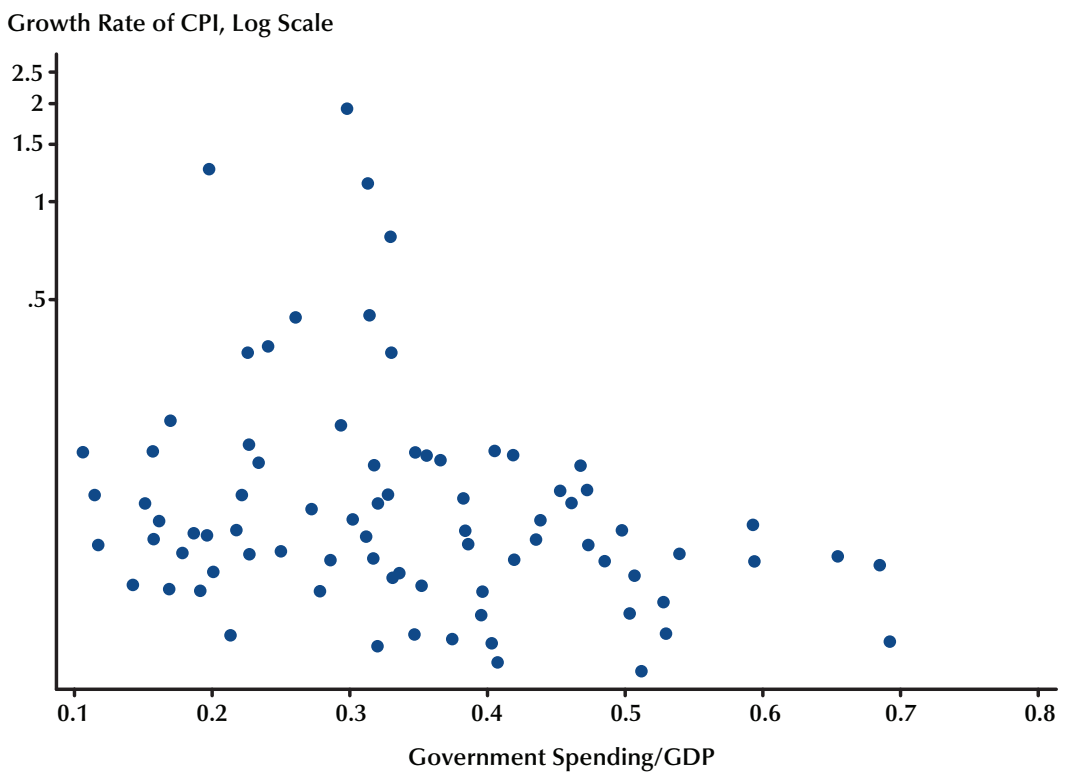

a scatter diagram displaying the relationship between inflation and the size of government. The vertical axis measures the average growth rate of CPI, and the horizontal axis measures total government spending as a fraction of GDP. Note that, although the growth rate of CPI is measured as the log difference, we display this log difference on a log scale in the figures. We do so because inflation rates for a few countries are an order of magnitude larger than the inflation rates of most countries. Figure 2 is a scatter diagram with the average annual growth rates of CPI replaced by the average annual growth rates of M1 (again on a log scale).

Contrary to the conventional view, the figures show a negative relationship between inflation and the size of government. This negative correlation is confirmed in our regressions. Table 1 shows the regression results using the growth rate of CPI as the measure of inflation. (The results using the growth rate of M1 are similar, but are not shown.) The first four regressions (columns 1 through 4) use the whole sample, whereas the last four regressions (columns 5 through 8) exclude six countries that experienced hyperinflation during the sample period. ${ }^{8}$ The OLS regressions of inflation on government size (columns 1 and 5) show significant negative coefficients.

As discussed in the previous section, other variables such as defense spending may affect the relationship between inflation and the size of government. In the next set of OLS regressions (columns 2 and 6), we divide total government spending into defense and non-defense spending (all as fractions of GDP). The results indicate that inflation is positively but statistically insignificantly correlated with defense spending, but negatively and statistically significantly correlated with non-defense spending. These coefficients suggest that the observed negative relationship

\footnotetext{
8 There is no consensus on the definition of hyperinflation. The six countries we exclude are those countries that adopted dramatic policies, including changing their currencies to fight against inflation during 1973-90: Argentina, Bolivia, Brazil, Chile, Nicaragua, and Uruguay. The static theory of inflation and public finance suggests one reason for separating the "hyperinflation" countries from the rest-hyperinflation countries may be those that are not on the upward-sloping portion of their non-inflation tax Laffer curves. Another reason is that those countries appear to be outliers on Figures 1 and 2 .
} 
Figure 2

Growth Rate of M1 and Government Size, 1973 to 1990

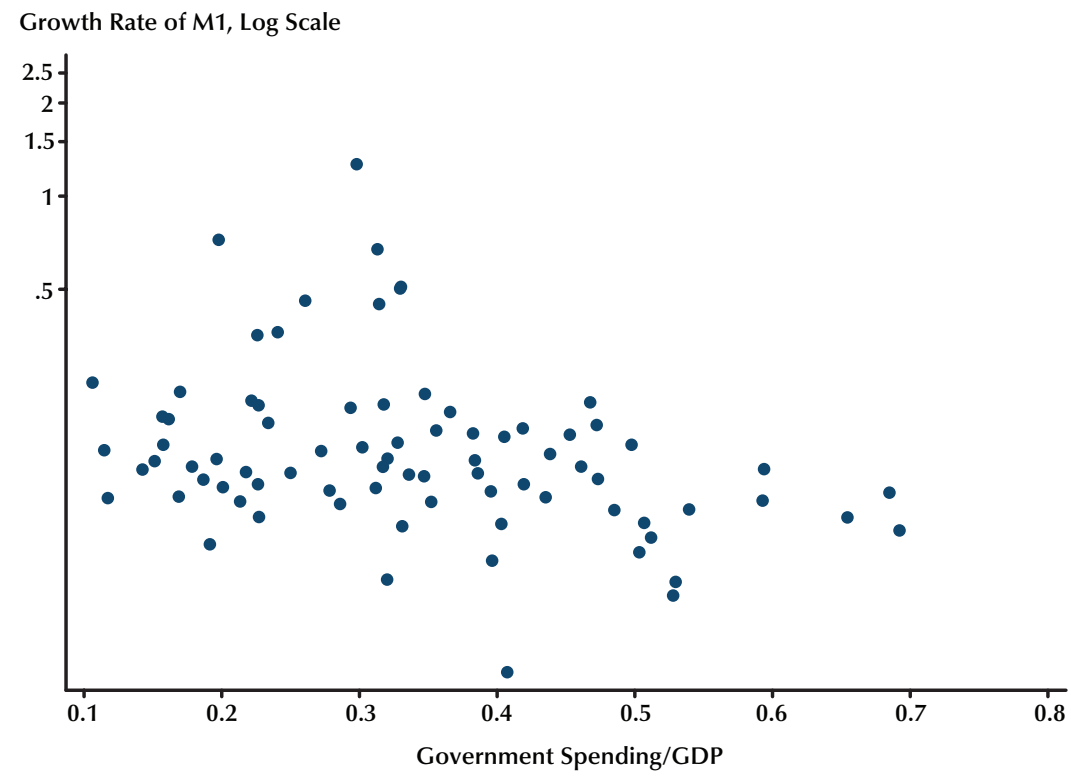

\section{Table 1}

Cross-Country Inflation Regressions, 1973-90 Averages

Dependent variable $=\mathbf{l o g}$ (average annual CPI growth rate)

\begin{tabular}{|c|c|c|c|c|c|c|c|c|}
\hline \multirow[b]{2}{*}{ Independent variables } & \multicolumn{4}{|c|}{ All countries } & \multicolumn{4}{|c|}{$\begin{array}{l}\text { Excluding countries that } \\
\text { experienced hyperinflation }\end{array}$} \\
\hline & (1) & (2) & (3) & (4) & (5) & (6) & (7) & (8) \\
\hline Government spending/GDP & $\begin{array}{c}-1.49 \\
(0.61)\end{array}$ & & $\begin{array}{c}-1.84 \\
(0.93)\end{array}$ & & $\begin{array}{c}-1.04 \\
(0.41)\end{array}$ & & $\begin{array}{c}-1.90 \\
(0.63)\end{array}$ & \\
\hline Non-defense spending/GDP & & $\begin{array}{c}-1.57 \\
(0.63)\end{array}$ & & $\begin{array}{c}-1.82 \\
(0.94)\end{array}$ & & $\begin{array}{c}-1.14 \\
(0.41)\end{array}$ & & $\begin{array}{c}-1.89 \\
(0.62)\end{array}$ \\
\hline Defense spending/GDP & & $\begin{array}{c}0.99 \\
(3.43)\end{array}$ & & $\begin{array}{c}0.98 \\
(3.43)\end{array}$ & & $\begin{array}{c}1.98 \\
(2.27)\end{array}$ & & $\begin{array}{l}1.96 \\
(2.32)\end{array}$ \\
\hline Regression method & OLS & OLS & IV & IV & OLS & OLS & IV & IV \\
\hline Number of countries & 80 & 80 & 80 & 80 & 74 & 74 & 74 & 74 \\
\hline$R^{2}$ & 0.07 & 0.08 & 0.07 & 0.08 & 0.08 & 0.11 & 0.13 & 0.14 \\
\hline
\end{tabular}

NOTE: Figures in parentheses are standard errors. The instrumental variable in the IV regressions is the average of the ratio of Social Security spending to GDP in 1973-90. 


\section{Han and Mulligan}

between inflation and government size shown in Figures 1 and 2 is driven mostly by the negative relation between inflation and non-defense spending. The results also suggest that the conventional view on the link between inflation and government size may be true only when defense spending represents a very important share of total government spending, for example, during wartime. But from cross-country regressions we cannot tell whether the temporary nature of wartime is important for the relationship between inflation and the size of government, as is suggested by the "inflation as a state-contingent debt manager" model. This issue is better analyzed with the timeseries data, as presented in the next section.

The coefficients of the OLS regressions may be biased because, as discussed in the previous section, government spending, especially nondefense spending, may respond to inflation and hence be endogenous. We use the ratio of Social Security spending to GDP as an IV for government size and non-defense spending. The ratio of Social Security spending to GDP is a reasonable IV because, first, it is correlated with government size and especially non-defense spending other than Social Security spending. In the cross-country data, the correlation between Social Security spending and non-Social Security non-defense spending (both as a fraction of GDP) is 0.44. (See also discussions on the correlation by, e.g., Mulligan and Sala-i-Martin, 1999 and 2004.) Second, because most countries rely exclusively on payroll taxes to finance Social Security spending, ${ }^{9}$ there is no need for a government to use the inflation tax to finance it. We note that in some countries, such as the United States, Social Security payments are indexed to the changes in the cost of living. However, because the changes in the cost of living and the changes in the GDP price deflator are highly correlated, the ratio of Social Security spending to output may not necessarily change with the cost of living. In other words, inflation is unlikely to be correlated directly with the ratio of Social Security spending to GDP.

9 The cross-country correlation between Social Security spending and payroll taxes is high (about 0.87 in our sample). The high propensity to finance Social Security out of payroll taxes is itself evidence that the inflation tax is not a substantial source of revenue.
The IV estimates using the whole sample (columns 3 and 4) are similar to the OLS estimates. The results using the sample that excludes the hyperinflation countries (columns 7 and 8) are similar to those using the whole sample, except that the magnitudes of the effects of defense spending on inflation are stronger, although still statistically insignificant.

We now include in our inflation regressions other factors that are correlated with government: central bank independence, the budget deficit, and the output level. First, it is often believed that, because price stability is a chief goal of central banks, a more independent central bank leads to lower inflation rates (see, e.g., Cukierman, 1992). We use two measures of central bank independence taken from Cukierman (1992). The first one is a ranking of central bank legal independence in the 1980s, and the second is the turnover rate of central bank governors during the period 1950-89.

Government debt or deficit can also be a potential determinant of the inflation tax. Because the inflation tax can be used as a direct way to generate seigniorage or reduce the real value of outstanding government debts, governments with larger nominal government debts would be inclined to inflate more (e.g., Barro and Gordon, 1983a, and Cukierman, Edwards, and Tabellini, 1992). When determining inflation in the "steady state" of a dynamic model or the static model, however, only the initial debt-to-GDP ratio matters. This is because, given the initial debt level, governments optimally choose the amount of debts and inflation over time (Cukierman, Edwards, and Tabellini, 1992). So what we are really interested in is a reduced-form relation with the initial debtto-GDP ratio as one of the exogenous variables. Based on this, we add the initial debt-to-GDP ratio to our regressions. ${ }^{10}$ The debt used is defined as total public debts minus that held by monetary authorities. The data used to calculate the ratios are from 1973 or the year with nonmissing observations closest to 1973.

\footnotetext{
${ }^{10}$ We also conducted experiments with an average deficit-to-GDP ratio in the sample period, instead of initial debt-to-GDP ratio. The regression results with this alternative measure (not shown here) are similar.
} 


\section{Table 2}

\section{Cross-Country Inflation Regressions, 1973-90 Averages with Measures of Central Bank Independence Dependent variable $=\log$ (average annual CPI growth rate)}

\begin{tabular}{|c|c|c|c|c|c|c|c|c|}
\hline \multirow[b]{2}{*}{ Independent variables } & \multicolumn{4}{|c|}{ All countries } & \multicolumn{4}{|c|}{$\begin{array}{l}\text { Excluding countries that } \\
\text { experienced hyperinflation }\end{array}$} \\
\hline & (1) & (2) & (3) & (4) & (5) & (6) & (7) & (8) \\
\hline Government spending/GDP & & & & $\begin{array}{c}0.74 \\
(0.83)\end{array}$ & & & & $\begin{array}{c}1.02 \\
(0.85)\end{array}$ \\
\hline Non-defense spending/GDP & $\begin{array}{l}-1.76 \\
(0.81)\end{array}$ & $\begin{array}{c}-0.15 \\
(0.74)\end{array}$ & $\begin{array}{c}0.80 \\
(0.85)\end{array}$ & & $\begin{array}{c}-1.38 \\
(0.62)\end{array}$ & $\begin{array}{c}-0.82 \\
(0.78)\end{array}$ & $\begin{array}{c}0.17 \\
(0.86)\end{array}$ & \\
\hline Defense spending/GDP & $\begin{array}{l}-2.33 \\
(7.48)\end{array}$ & $\begin{array}{l}-2.95 \\
(6.07)\end{array}$ & $\begin{array}{l}-3.48 \\
(6.14)\end{array}$ & & $\begin{array}{l}-2.82 \\
(5.92)\end{array}$ & $\begin{array}{l}-3.10 \\
(5.97)\end{array}$ & $\begin{array}{l}-4.05 \\
(5.68)\end{array}$ & \\
\hline CB legal independence in 1980s & & $\begin{array}{c}-0.06 \\
(0.81)\end{array}$ & $\begin{array}{c}0.06 \\
(0.78)\end{array}$ & $\begin{array}{c}0.07 \\
(0.78)\end{array}$ & & $\begin{array}{l}-0.21 \\
(0.81)\end{array}$ & $\begin{array}{l}-0.09 \\
(0.75)\end{array}$ & $\begin{array}{c}-0.08 \\
(0.75)\end{array}$ \\
\hline CB governor turnover rate, $1950-89$ & & $\begin{array}{c}3.17 \\
(0.67)\end{array}$ & $\begin{array}{c}3.03 \\
(0.64)\end{array}$ & $\begin{array}{c}3.01 \\
(0.64)\end{array}$ & & $\begin{array}{c}1.25 \\
(1.05)\end{array}$ & $\begin{array}{c}0.79 \\
(1.00)\end{array}$ & $\begin{array}{c}0.75 \\
(0.99)\end{array}$ \\
\hline Public debt/GDP, 1973 & & & $\begin{array}{c}-0.21 \\
(0.56)\end{array}$ & $\begin{array}{c}-0.31 \\
(0.53)\end{array}$ & & & $\begin{array}{c}-0.19 \\
(0.66)\end{array}$ & $\begin{array}{c}-0.27 \\
(0.65)\end{array}$ \\
\hline Average log (real GDP per capita) & & & $\begin{array}{c}-0.29 \\
(0.13)\end{array}$ & $\begin{array}{c}-0.28 \\
(0.12)\end{array}$ & & & $\begin{array}{c}-0.34 \\
(0.12)\end{array}$ & $\begin{array}{c}-0.33 \\
(0.12)\end{array}$ \\
\hline Number of countries & 43 & 43 & 43 & 43 & 40 & 40 & 40 & 40 \\
\hline$R^{2}$ & 0.11 & 0.44 & 0.51 & 0.51 & 0.12 & 0.21 & 0.33 & 0.31 \\
\hline
\end{tabular}

NOTE: CB is central bank. Figures in parentheses are standard errors. All regressions are OLS.

The third variable we add to our regressions is real GDP per capita (in logs). It has been suggested that a country's wealth is a good indicator of the efficiency of the non-inflation taxes (e.g., Cukierman, Edwards, and Tabellini, 1992, and Click, 1998). Also, much has been written on whether there is any relationship between inflation and output in the long run. If inflation is related to output, it may induce spurious effects on the relation between inflation and government size because the latter is defined as the ratio of government spending to GDP. So including real GDP per capita can also reduce these possible effects.

The results of the OLS and IV estimations with the above additional variables are shown in Tables 2 and 3, respectively. As in Table 1, we show two sets of regressions: one using the whole sample (columns 1 through 4 in Table 2 and 1 through 6 in Table 3) and another excluding countries that experienced hyperinflation during the period 1973-90 (columns 5 through 8 in Table 2 and 7 through 12 in Table 3). ${ }^{11}$ Because indices of central bank independence are available only for about half of the countries, the sample size is reduced substantially. Comparing the OLS regressions (columns 1 and 5 in Table 2 and 1 and 7 in Table 3 with columns 2 and 6 in Table 1), it appears that the smaller sample size changes the signs of the estimated relation between inflation and defense spending from positive to negative, although they are still statistically insignificant. But the smaller sample size seems to have no qualitative effects on the estimated relation between inflation and non-defense spending. For non-defense spending, the coefficients are

${ }^{11}$ The countries excluded are Argentina, Chile, and Uruguay. 


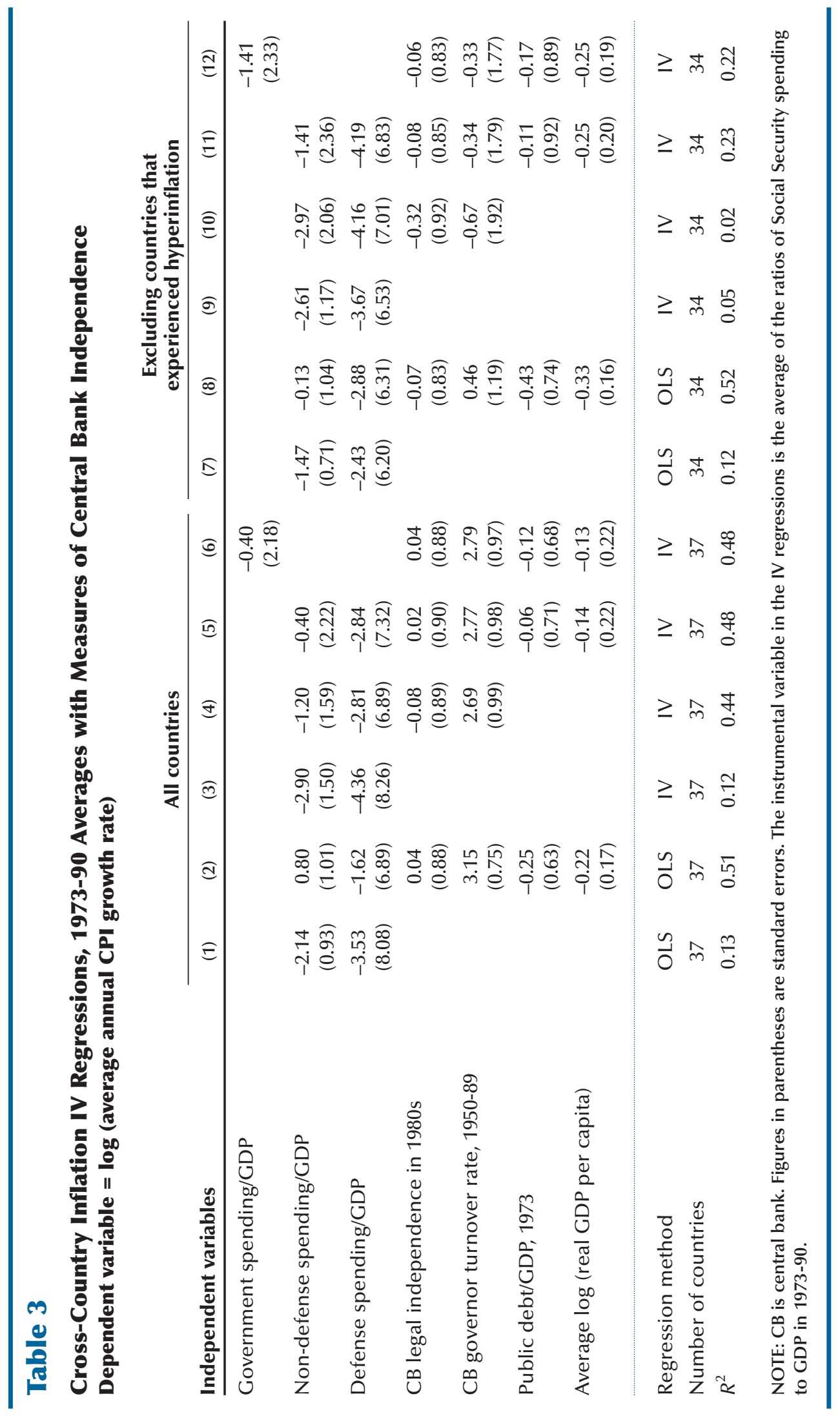


still negative and significant. The same observation can be made when comparing the IV regressions (columns 3 and 9 in Table 3 with columns 4 and 8 in Table 1). With other variables included in the regressions, the OLS and IV regressions using both samples show that inflation is still negatively related to non-defense spending, but the effects become statistically insignificant. The relation between inflation and defense spending is also negative and statistically insignificant.

Other findings are as follows: First, the effects of central bank legal independence on inflation are very weak (in terms of $t$-statistics) and change signs from one regression to another. With the whole sample, both the OLS and IV estimations show that inflation is significantly positively related to the turnover rate of central bank governors. With the three hyperinflation countries excluded, the relation is positive in the OLS regressions and negative in the IV regressions and none of them is statistically significant. This suggests that, first, independence written on paper means little if central bank governors can be easily removed in reality; second, in determining inflation, central bank independence matters only in countries that have experienced hyperinflation. Those countries are presumably those that are not on the upward-sloping portion of their noninflation tax Laffer curves.

Second, all regressions show that inflation is weakly negatively related to initial debt-to-GDP ratios. If we think of redemption of initial debt as part of total government spending, the negative relation seems consistent with the relation between inflation and non-defense spending. We also find that inflation is negatively related to real GDP per capital (in logs) in all regressions. This relation is significant except in the IV regressions: The negative relations suggest that countries with efficient tax systems tend to rely less on inflation to finance a given amount of government spending.

In summary, the cross-country exercises show that, first, the correlation between inflation and government size is negative but weak. ${ }^{12}$ The negative correlation is driven mainly by the negative relation between inflation and non-defense spending. Second, with the whole sample of 80 countries, inflation is significantly positively related to defense spending. So, when defense spending is an important fraction of total government spending, the conventional view that inflation is positively related to government size holds. When we include only those countries for which central bank independence data are available, inflation is shown weakly negatively related to defense spending. Our analysis strongly suggests that the switch of signs of the estimates is caused mainly by sample attrition. Finally, the regressions also suggest that inflation may be indeed negatively related to central bank independence, especially for countries that have experienced hyperinflation. Also, inflation is shown to be weakly negatively related to the initial debt-toGDP ratio and more strongly negatively related to real GDP per capita.

\section{TIME-SERIES EVIDENCE}

The above cross-country analysis is suitable for studying the relation between inflation and government size in the steady state of a dynamic model or in a static model, which tells us how inflation responds to long-run or permanent changes in government spending. To find out how governments inflate and deflate in response to temporary changes in government spending, we have to turn to time-series data. We study this issue using U.S. and U.K. time-series data.

\section{The United States}

For the United States, government size is defined as the ratio of federal government outlays to national income. ${ }^{13}$ We use growth rates of CPI and M2 as measures of the inflation tax. The data,

\footnotetext{
${ }^{12}$ Although the inflation tax rate and the size of government do not display a strong positive relationship across countries, other tax rates are correlated with the size of government. For example, regressions with the personal income tax rate show that some tax rates are positively correlated with government size (results not reported here). See also Click (1998).

${ }^{13}$ We use national income instead of gross national product (GNP) because we do not have data on GNP for the earlier years. The evidence using GNP (not shown here) is similar to that using national income for the periods when we have data on both variables.
} 


\section{Figure 3}

\section{Inflation and Government Size and Its Components: United States, 1870-1995}

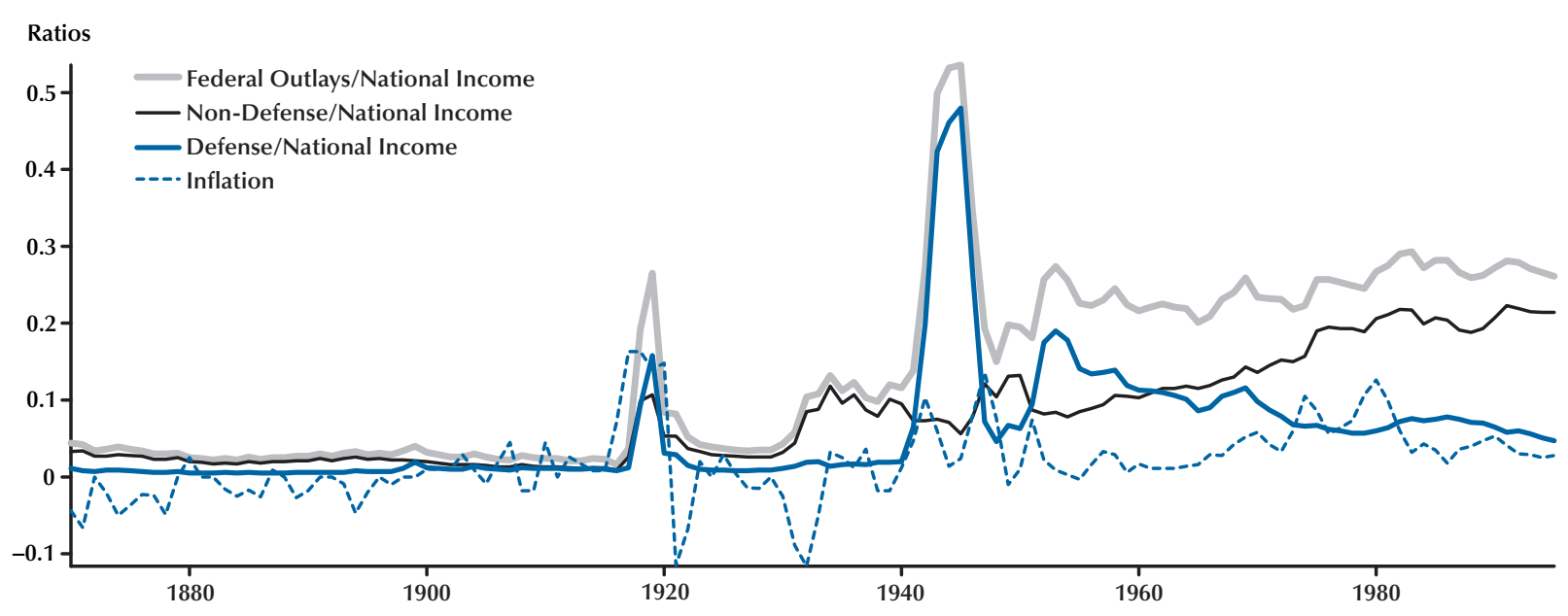

plotted in Figure 3, are annual time series for the period 1870-1995. ${ }^{14}$

The figure shows that roughly before 1930, federal government outlays as a fraction of national income (solid gray line) is small and stable, except during the large temporary increase during World War I. Since 1930, there has been a secular upward trend in government spending driven mainly by non-defense spending (thin black line). The large temporary increases in government spending, however, were driven mainly by defense spending (solid blue line), as shown by the spikes for World War II, the Korean War, and the Vietnam War. Defense spending seems to return to its steady state in the late 1970s, although the steady state seems higher than that in the prewar period. From the figure, it is not clear how inflation (dashed blue line) is related to government spending, except that inflation during wartime is usually higher than the normal levels.

The regression results are shown in Table 4. Regressions in panel A use the growth rate of CPI as the dependent variable, whereas those in panel B use the growth rate of M2. In addition to

\footnotetext{
14 The data are from the Historical Statistics of the United States, 1790-1970 (Dodd, 1973) and the Economic Report of the President (various years).
}

government spending, we also include the ratio of government debt in year $t-1$ to national income in year $t$ in our regressions. The first four columns in both panels are OLS regressions using data for the entire sample period 1870-1995. All OLS regressions are estimated by assuming that the error terms follow AR(1) processes. The results show that the growth rate of CPI is positively related to non-defense spending but negatively related to defense spending. Because of price controls during wartime (e.g., World War II), however, the growth rate of CPI may not be a good measure of the inflation tax. Instead, the growth rate of the money supply may be a more reliable measure to test the public finance theory of inflation in the time-series context. The regressions shown in the first four columns of panel B indicate that the growth rate of M2 is weakly negatively related to non-defense spending and strongly positively related to defense spending and government size.

In the rest of the regressions in Table 4, we use data from only 1936-95. There are two reasons for considering the short sample period. First, before 1933, the United States was in the classical gold-standard period. With the gold standard, governments have only limited ways to generate revenue through the inflation tax. Hence, to test 


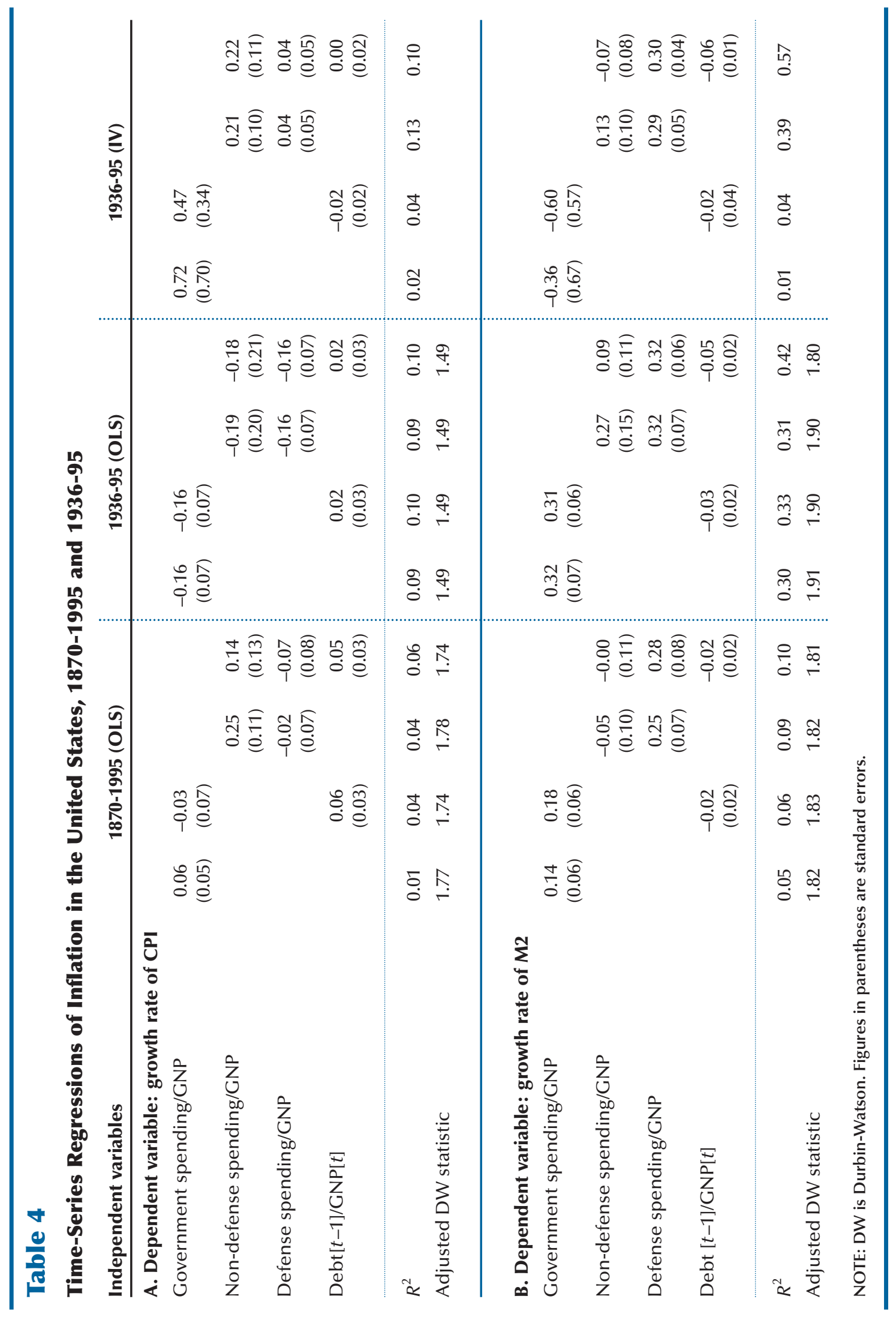




\section{Han and Mulligan}

the public finance theory of inflation, the appropriate economic system should be the paper standard. We will discuss this issue further in the fifth section. Second, as in the cross-country analysis, we would like to use Social Security spending (as a ratio of national income) as an IV for government spending (especially non-defense spending) to mitigate the potential bias caused by the endogeneity problem. But the Social Security program started only in the late 1930s.

The IV regressions for the period 1936-95 are shown in the last four columns of Table 4. To show the differences between OLS and IV regressions, in the middle four columns we reproduce the OLS regressions for the period. These results show that the growth rate of CPI is negatively related to both non-defense and defense spending as well as government size. The signs all change and become positive in the IV regressions. However, as discussed above, because of price controls during World War II, those coefficients may be downward-biased estimates of the relation between the inflation tax and government size. The results in panel B show that, for the period 1936-95, the growth rate of M2 is positively related to both non-defense and defense spending in both the OLS and IV regressions. Moreover, the coefficients for defense spending are all statistically significant while those for non-defense spending are not significant.

It is also interesting to note that the growth rate of M2 is shown to be positively related to government size in all OLS regressions in panel B. But the signs all change and become negative in the IV regressions. It is important to note that Social Security spending is a better IV for nondefense spending than for government size. The correlation between Social Security spending and non-defense spending is 0.80 , while the correlation between Social Security spending and government size is only 0.15 . So the IV results for non-defense spending are more reliable than those for government size.

Finally, the growth rate of M2 is weakly negatively related to the lagged debt-to-national income ratios, as we have seen in the cross-country analysis.
In summary, the evidence based on the U.S. time-series data shows that inflation is strongly positively related to government size and the relation is driven mainly by the strong positive relation between inflation and defense spending. The relation between inflation and non-defense spending is ambiguous and statistically weak.

\section{The United Kingdom}

We now turn to the U.K. time series for the period 1721-1990. We measure government size by total central government spending as a fraction of GNP. We also compute the ratios of defense and non-defense spending to GNP. Inflation is measured by growth rates of CPI and M1. ${ }^{15}$ The time series are plotted in Figure 4. The first noticeable feature of the figure is that the spikes for the size of government (solid gray line) are mainly due to the sharp increases in defense spending (solid blue line). The United Kingdom fought several wars during the sample period, resulting in unusually large temporary increases in defense spending (as a fraction of GNP).

As with the U.S. time series, the U.K. time series show a secular upward trend in government spending (as a fraction of GNP) after World War II and the trend seems to be associated mainly with the increases in the size of non-defense spending (thin black line). On the other hand, the fractions for defense spending are about the same in the entire sample period, except during the wars. Finally, as with the United States, it is not clear how U.K. inflation (dashed blue line) is related

\footnotetext{
15 The data on price levels are from McCusker (1992). The data used to calculate the growth rate of money for the period 1720-1921 are bank notes of the Bank of England from Mitchell (1988, pp. 655-70) and since 1922 are M1 from Mitchell (1988, pp. 674, and 1998, pp. 813-23). The data on central government spending for the period 1700-1801 are net public expenditures from Mitchell (1988, pp. 578-80), for 1801-1980 are gross public expenditures from Mitchell (1988, pp. 587-95), and for 1981-90 are central government expenditures from the United Nations $(1985,1994)$. The data on defense spending for the period 1700-1980 are from Mitchell (1988, pp. 578-80, 587-95), which combine the spending for the army, ordinances, naval and air forces, special expeditions, and votes of credits. For the period after 1980, the data on defense spending are from the United Nations $(1985,1994)$. The data on GNP for the period 1830-1980 are from Mitchell (1988, pp. 831-36) and for 1980-90 are from the United Nations $(1985,1994)$. For the period 1700-1830, Deane (1967, pp. 78, 282) provides estimates on the 10-year growth rate of real GNP. To obtain estimates within a decade, we interpolate this series according to the average annual growth rate of GNP in a decade.
} 


\section{Figure 4}

\section{Inflation and Government Size and Its Components: United Kingdom, 1721-1990}

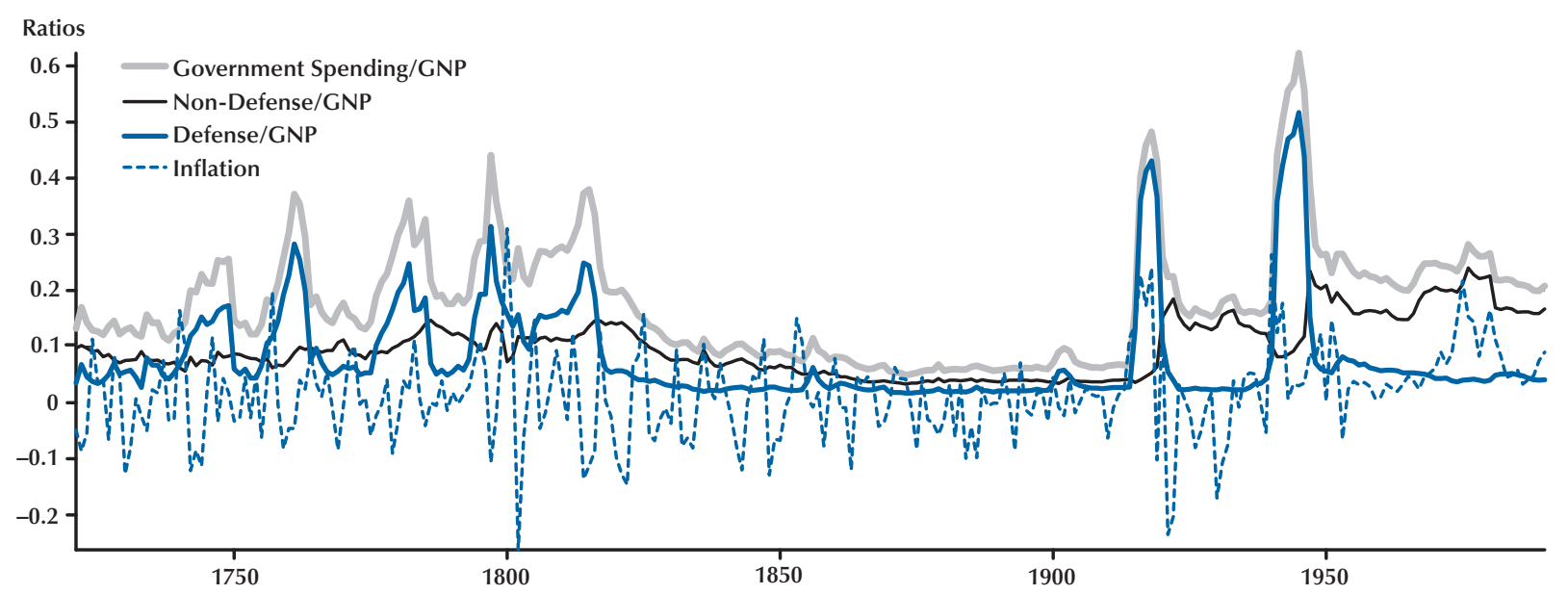

to government spending, except that inflation during wartime is usually higher than the normal levels. This is especially true in the paperstandard period, which is further discussed in the next section.

The time-series regressions using the growth rates of CPI (panel A) and M1 (panel B) as dependent variables are shown in Table 5. As in the analysis of the U.S. time series, we consider regressions using both the entire sample period and the paper-standard period 1932-90. All regressions are OLS and assume that the error terms are AR(1) processes.

The results are similar to what we obtain using the U.S. time series. First, with the entire sample period, the growth rates of both CPI and M1 are positively related to government size as well as defense and non-defense spending. In particular, the relation is statistically significant for the growth rate of M1. Second, for the paperstandard period, the growth rates of both CPI and M1 are positively related to defense spending, but ambiguously related to non-defense spending. The relation between the growth rate of CPI and the size of government is also not clear.

We also find that, as in the U.S. time series and cross-country analysis, the growth rates of both CPI and M1 are negatively related to the debt-to-GNP ratio. The main difference is that for the U.K. time series the relations are statistically significant in all regressions

In summary, as in the U.S. time-series analysis, we find that inflation is positively related to government size, which is driven mainly by the positive relation between inflation and defense spending. The relation between inflation and non-defense spending is ambiguous and statistically weak.

\section{WARTIME INFLATION AND SUSPENSION OF CONVERTIBILITY}

In the previous section, we provided a statistical analysis of the effects of the stochastic changes in the size of government on inflation. In this section, we look specifically into the behavior of inflation during periods when large and temporary changes in the size of government are induced by war.

In British and American history, temporarily high levels of government spending-especially defense spending associated with major warswere often financed by public debts that were 


\section{Table 5}

\section{Time-Series Regressions of Inflation in the United Kingdom, 1721-1990 and 1932-90}

\begin{tabular}{|c|c|c|c|c|c|c|c|c|}
\hline \multirow{2}{*}{\multicolumn{2}{|c|}{$\frac{\text { Independent variables }}{\text { A. Dependent variable: growth rate of CPI }}$}} & \multicolumn{3}{|c|}{$1721-1990$} & \multicolumn{4}{|c|}{$1932-90$} \\
\hline & & & & & & & & \\
\hline Government spending/GNP & $\begin{array}{c}0.10 \\
(0.06)\end{array}$ & $\begin{array}{c}0.21 \\
(0.06)\end{array}$ & & & $\begin{array}{c}-0.10 \\
(0.12)\end{array}$ & $\begin{array}{c}0.08 \\
(0.10)\end{array}$ & & \\
\hline Non-defense spending/GNP & & & $\begin{array}{c}0.18 \\
(0.13)\end{array}$ & $\begin{array}{c}0.33 \\
(0.12)\end{array}$ & & & $\begin{array}{c}0.37 \\
(0.31)\end{array}$ & $\begin{array}{c}0.38 \\
(0.30)\end{array}$ \\
\hline Defense spending/GNP & & & $\begin{array}{c}0.07 \\
(0.07)\end{array}$ & $\begin{array}{c}0.17 \\
(0.07)\end{array}$ & & & $\begin{array}{c}0.04 \\
(0.10)\end{array}$ & $\begin{array}{c}0.11 \\
(0.10)\end{array}$ \\
\hline Debt[t-1]/GNP[t] & & $\begin{array}{c}-0.03 \\
(0.01)\end{array}$ & & $\begin{array}{c}-0.03 \\
(0.01)\end{array}$ & & $\begin{array}{c}-0.04 \\
(0.02)\end{array}$ & & $\begin{array}{c}-0.03 \\
(0.02)\end{array}$ \\
\hline$R^{2}$ & 0.01 & 0.06 & 0.01 & 0.06 & 0.01 & 0.07 & 0.03 & 0.09 \\
\hline Adjusted DW statistic & 1.95 & 1.94 & 1.95 & 1.93 & 2.38 & 2.04 & 2.06 & 2.12 \\
\hline \multicolumn{9}{|c|}{ B. Dependent variable: growth rate of $M 1$} \\
\hline Government spending/GNP & $\begin{array}{c}0.27 \\
(0.06)\end{array}$ & $\begin{array}{c}0.39 \\
(0.07)\end{array}$ & & & $\begin{array}{c}0.13 \\
(0.18)\end{array}$ & $\begin{array}{c}0.32 \\
(0.17)\end{array}$ & & \\
\hline Non-defense spending/GNP & & & $\begin{array}{c}0.39 \\
(0.13)\end{array}$ & $\begin{array}{c}0.56 \\
(0.13)\end{array}$ & & & $\begin{array}{c}-0.08 \\
(0.60)\end{array}$ & $\begin{array}{c}-0.12 \\
(0.49)\end{array}$ \\
\hline Defense spending/GNP & & & $\begin{array}{c}0.22 \\
(0.07)\end{array}$ & $\begin{array}{c}0.34 \\
(0.08)\end{array}$ & & & $\begin{array}{c}0.10 \\
(0.19)\end{array}$ & $\begin{array}{c}0.29 \\
(0.16)\end{array}$ \\
\hline Debt[t-1]/GNP[t] & & $\begin{array}{c}-0.04 \\
(0.01)\end{array}$ & & $\begin{array}{c}-0.04 \\
(0.01)\end{array}$ & & $\begin{array}{c}-0.09 \\
(0.03)\end{array}$ & & $\begin{array}{c}-0.09 \\
(0.03)\end{array}$ \\
\hline$R^{2}$ & 0.06 & 0.11 & 0.07 & 0.12 & 0.01 & 0.14 & 0.01 & 0.16 \\
\hline Adjusted DW statistic & 1.97 & 2.10 & 1.98 & 2.11 & 2.08 & 1.99 & 2.08 & 1.98 \\
\hline
\end{tabular}

NOTE: DW is Durbin-Watson. All regressions are OLS. Figures in parentheses are standard errors.

nominally denominated in their own currencies. Because of these nominal provisions, the theory of Lucas and Stokey (1983), Judd (1989), and others suggests that inflation serves as a statecontingent manager to adjust the real returns on the public debt. In particular, inflation would rise on the arrival of "bad" news-the start of a war-and fall on the arrival of "good" news—the end of a war. This reduces the real returns on the public debt during a war but raises the real returns when a war is over. This high expected real rate of return after a war induces people to buy government debt at reasonable prices and generates the necessary revenues for fighting a war. Moreover, the theory also suggests that, from the viewpoint of optimal taxation, inflation can be desirable in the event of temporary increases in government spending because ex post inflation serves as a tax on a stock variable-money holding — as a kind of "capital levy." In both arguments, through the adjustment of inflation, government achieves a certain degree of smoothness of total taxes across different states and reduces the distortion of taxation.

The presumptions of the previously mentioned state-contingent theory are that the government has the ability to adjust inflation contingent 


\section{Table 6}

\section{Inflation and Money Growth Rates During Suspensions of Convertibility in the Classical Gold-Standard Periods in the United Kingdom and United States}

\begin{tabular}{|c|c|c|c|c|c|c|c|}
\hline \multirow[b]{2}{*}{ Episodes } & \multirow[b]{2}{*}{$\begin{array}{l}\text { Number } \\
\text { of periods }\end{array}$} & \multicolumn{3}{|c|}{ Inflation } & \multicolumn{3}{|c|}{ Money growth rate* } \\
\hline & & $\begin{array}{l}\text { Mean (standard } \\
\text { deviation) }\end{array}$ & Minimum & Peak & $\begin{array}{l}\text { Mean (standard } \\
\text { deviation) }\end{array}$ & Minimum & Peak \\
\hline \multicolumn{8}{|l|}{ United Kingdom: 1717-1931 } \\
\hline 1797-1821 (paper pound) & 25 & $0.00(0.12)$ & -0.26 & 0.31 & $0.03(0.08)$ & -0.08 & 0.20 \\
\hline $\begin{array}{l}\text { 1797-1802 } \\
\text { (French Revolutionary War }\end{array}$ & r) & $0.02(0.20)$ & -0.26 & 0.31 & $0.08(0.09)$ & -0.04 & 0.20 \\
\hline 1803-15 (Napoleonic War) & 13 & $0.01(0.09)$ & -0.14 & 0.15 & $0.04(0.07)$ & -0.06 & 0.18 \\
\hline $1914-25$ & 12 & $0.04(0.16)$ & -0.23 & 0.24 & $0.10(0.14)$ & -0.06 & 0.35 \\
\hline 1914-19 (World War I) & 6 & $0.13(0.12)$ & -0.10 & 0.24 & $0.17(0.13)$ & 0.05 & 0.35 \\
\hline Non-suspension periods & 178 & $0.00(0.06)$ & -0.17 & 0.20 & $0.01(0.10)$ & -0.41 & 0.41 \\
\hline \multicolumn{8}{|l|}{ United States: 1792-1933 } \\
\hline $1862-79$ & 18 & $0.01(0.09)$ & -0.07 & 0.22 & $0.04(0.05)$ & -0.05 & 0.12 \\
\hline $\begin{array}{l}\text { 1862-65 } \\
\text { (American Civil War) }\end{array}$ & 4 & $0.15(0.09)$ & 0.04 & 0.22 & $\mathrm{~N} / \mathrm{A}$ & $\mathrm{N} / \mathrm{A}$ & $\mathrm{N} / \mathrm{A}$ \\
\hline Non-suspension periods & 124 & $0.00(0.06)$ & -0.17 & 0.18 & $0.05(0.06)$ & -0.12 & 0.17 \\
\hline
\end{tabular}

NOTE: *For the United Kingdom, the money growth rate is the growth rate of M1; data are available only since 1721 . For the United States, the money growth rate is the growth rate of $\mathrm{M} 2$; data are available only since 1868 .

on the event of a war and that the government should also show the public that it commits to such a contingent policy. In the classical gold standard system, suspension of convertibility (and/or lowering of conversion ratios) serves as a tool to effectively raise inflation at the start of a war because it allows the government to print paper money to generate more seigniorage. Inflation in turn also reduces the real value of government's debt payments during the war. At the same time, resumption of convertibility shows government commitment to the state-contingent policy (Bordo and Kydland, 1996). Hence, the statecontingent theory of inflation implies that inflation is high at the beginning and during suspensions of convertibility and low when convertibility resumes.

There are two episodes of suspension of convertibility in the United Kingdom in the U.K. classical gold-standard period (1717-1931): 17971821, because of the war with France (1793-1815); and 1914-1925, because of World War I. In the
United States, there is one episode of suspension of convertibility in the U.S. classical gold-standard period (1792-1933): 1862-79, because of the Civil War (1862-65). In Table 6, we compare inflation and money growth during these episodes of suspension with those during the non-suspension gold-standard periods.

On average, as Table 6 shows, inflation and the money growth rate are higher in the suspension than the non-suspension periods. For example, in the United Kingdom, the average inflation is essentially 0 and the M1 growth rate is 0.01 in the non-suspension periods, whereas the average inflation ranges from 0.01 to 0.13 and the average M1 growth rate from 0.03 to 0.17 in the two wartime suspension periods. The same pattern also exists in the U.S. episode. Note that, because in all cases convertibility did not resume until several years after a war ended, the inflation and money growth rates had to be much lower at the end of each suspension period in order to reach the low inflation in the non-suspension periods. 
Figure 5

\section{Wartime Inflation During Suspensions of Convertibility in the Classical Gold Standard Period and in the Paper Standard Period: United Kingdom, 1721-1990}
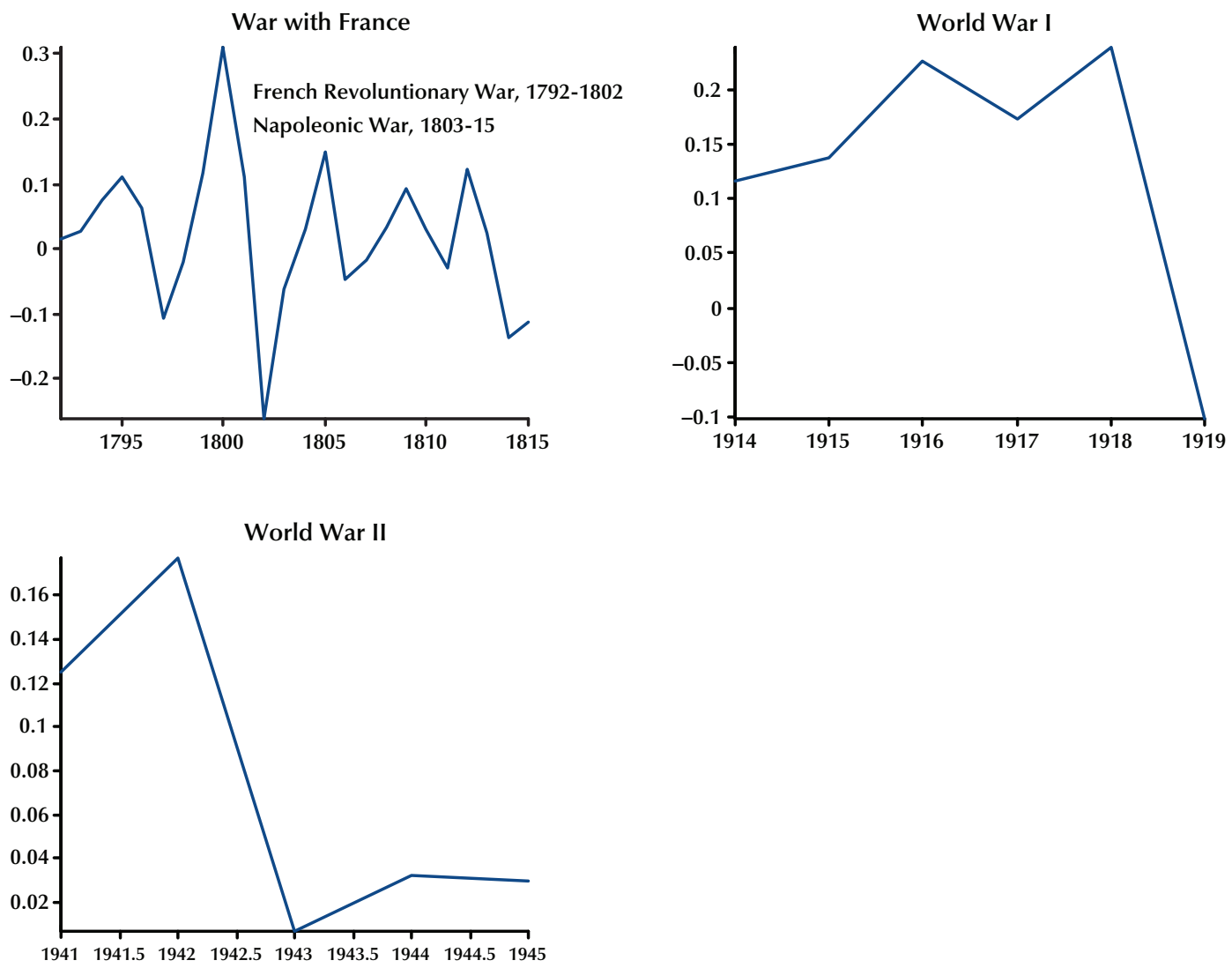

To see this, we plot time series for U.K. (top two panels of Figure 5) and U.S. (top left panel of Figure 6) inflation during these episodes.

As we can see, inflation even started to fall at the end of each war. U.K. inflation during World War $\mathrm{I}^{16}$ and U.S. inflation during the Civil War are high at the beginning of the wars, reach peaks during the wars, and are low or become negative at the end of or immediately after the wars. U.K. inflation seems to behave differently during the

${ }^{16}$ Inflation in both the United Kingdom and the United States did not decline until a couple of years after the end of World War I. However, although official fighting in World War I ended on November 11, 1918, when the armistice was declared, the peace itself was not established until the Treaty of Versailles was signed on June 28, 1919, and it did not go into effect until January 10, 1920. war with France (1793-1815), which has two phases: the French Revolutionary War (1792-1802) and the Napoleonic War (1803-15). The first trough of inflation matches the end of the French

Revolutionary War, in which Britain was a winner. After a brief truce, war begins again in 1803; inflation rises above the normal level again then falls at the end of the war.

In short, the above analysis shows that, in the classical gold-standard periods, suspension and resumption of convertibility serve as a statecontingent manager to adjust (i) inflation and (ii) the real returns on government debts during periods in which there is a temporary need for increased revenues. As a result, inflation is high at the beginning of the wars and suspension of 


\section{Figure 6}

\section{Wartime Inflation During Suspensions of Convertibility in the Classical Gold Standard Period and in the Paper Standard Period: United States, 1792-1995}
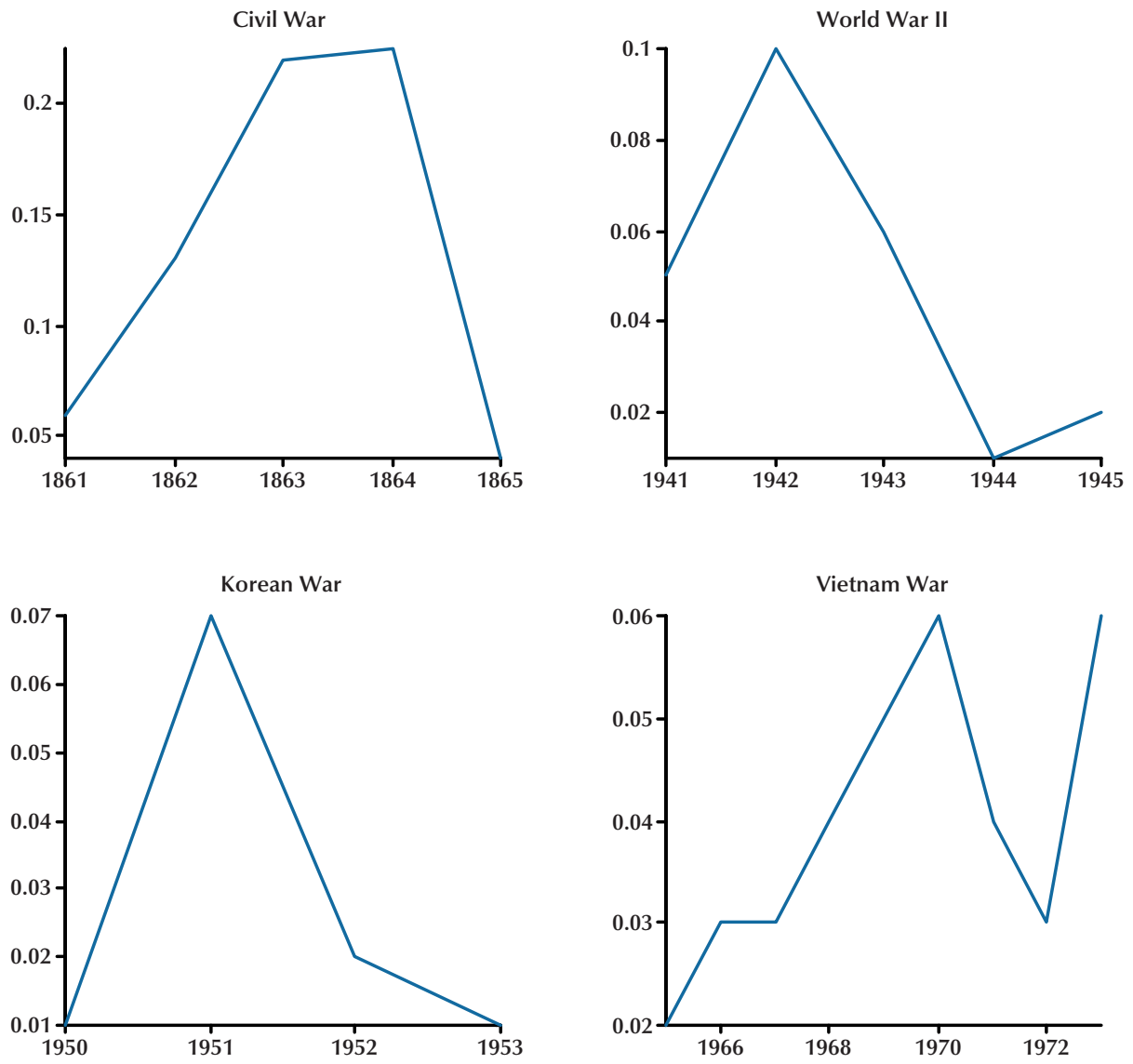

convertibility and low at the end of the wars and the resumption of convertibility.

The above observations on inflation during the suspension of convertibility in the classical gold-standard periods also hold for wars after the classical gold-standard periods. Table 7 shows the summary statistics of inflation during wars since 1933. The time series for inflation during these times of war are plotted in Figure 5 for the United Kingdom (lower panel) and Figure 6 for

${ }^{17}$ For both the United Kingdom and the United States, inflation remained at high levels after Word War II. Grossman (1990) argues that the continuing high inflation after World War II can be explained by the changes in factors increasing the power of debtors relative to that of creditors in the political process and the large demands the United States (top-right and lower panels). In all cases except the Vietnam War (1965-73), ${ }^{17}$ inflation is high at the beginning, reaches a peak in the middle, and is low at the conclusion of a war. This supports the theory that inflation is above normal on the receipt of "bad news" of government fiscal situations-the start of a warand below normal upon the receipt of "good news"- the end of war.

For the United States, inflation rose at the end of the Vietnam War. Note that the Vietnam War is one of the few wars since U.S. independence

on national resources for huge postwar reconstruction and maintenance of a nuclear arsenal. 
Table 7

Inflation and Money Growth Rates During Wars in the Post-Classical Gold-Standard Periods in
the United Kingdom and United States

\begin{tabular}{|c|c|c|c|c|c|c|c|}
\hline \multirow[b]{2}{*}{ Episodes } & \multirow[b]{2}{*}{$\begin{array}{c}\text { Number } \\
\text { of periods }\end{array}$} & \multicolumn{3}{|c|}{ Inflation } & \multicolumn{3}{|c|}{ Money growth rate* } \\
\hline & & $\begin{array}{c}\text { Mean (standard } \\
\text { deviation) }\end{array}$ & Minimum & Peak & $\begin{array}{l}\text { Mean (standard } \\
\text { deviation) }\end{array}$ & Minimum & Peak \\
\hline \multicolumn{8}{|l|}{ United Kingdom: 1932-90 } \\
\hline 1941-45 (World War II) & 5 & $0.07(0.07)$ & 0.00 & 0.17 & $0.15(0.03)$ & 0.12 & 0.21 \\
\hline Non-war periods & 54 & $0.06(0.06)$ & -0.07 & 0.26 & $0.08(0.11)$ & -0.06 & 0.80 \\
\hline \multicolumn{8}{|l|}{ United States: 1834-95 } \\
\hline 1941-45 (World War II) & 5 & $0.05(0.03)$ & 0.01 & 0.10 & $0.15(0.04)$ & 0.10 & 0.21 \\
\hline 1950-53 (Korean War) & 4 & $0.03(0.03)$ & 0.01 & 0.07 & $0.05(0.01)$ & 0.03 & 0.06 \\
\hline 1965-73 (Vietnam War) & 9 & $0.04(0.01)$ & 0.02 & 0.06 & $0.08(0.03)$ & 0.04 & 0.13 \\
\hline Non-suspension periods & 44 & $0.04(0.04)$ & -0.02 & 0.14 & $0.06(0.03)$ & -0.00 & 0.13 \\
\hline
\end{tabular}

NOTE: *For the United Kingdom, the money growth rate is the growth rate of M1; for the United States, it is the growth rate of M2.

that did not end in an unmistakable American victory. This suggests that ending a war alone is not always good news for a government's fiscal situation. For a defeated country, its government has to face tougher challenges, both economically and politically, to raise necessary revenues using only non-inflation taxes to meet the needs of postwar reconstructions, debt repayments, and, possibly, large war reparations. This provides more incentives for the government to rely on inflation as a revenue source. These episodes and the high inflations in the defeated countries ${ }^{18}$ after the two World Wars suggest that inflation responds strongly to the nature of how a war ends and the ability of a government to meet its future fiscal obligations.

\section{SUMMARY}

In this paper we review the implications of existing theories on the relationship between inflation and the size of government and study

\footnotetext{
${ }^{18}$ During Word War II, the Nazi government in Germany imposed strict prices to keep inflation low. After its defeat in 1945, currency reform was carried out. As a result, there was no high inflation in Germany. Other defeated countries such as Japan and Italy experienced high inflation after the war.
}

how the theoretical predictions match empirical evidence. We find that the strongest empirical relationship between inflation and the size of government arises from wartime. Inflation was fairly high during several British and American wars and often negative after wars. We also find that permanently high non-defense government spending-as observed across countries—seems to be weakly negatively related to inflation while defense spending is somewhat more strongly positively related. Also there has been a slight secular increase in inflation with the size of government over time, which we cannot account for with defense spending.

The static or steady-state Ramsey theory thus fails to predict the magnitude of the inflation tax. Not only is the theory ambiguous about the sign of the relationship between inflation and the size of government, it also fails to explain why wars are the best predictors of inflation and why the composition of government spending is correlated with inflation.

To the extent that wars are surprises, a dynamic stochastic Ramsey theory (such as Lucas and Stokey, 1983) does explain the strong correlation between inflation and temporary wartime government spending, although perhaps not the 
relationship with more permanent defense spending.

\section{REFERENCES}

Alesina, Alberto and Summers, Lawrence H.

"Central Bank Independence and Macroeconomic Performance: Some Comparative Evidence." Journal of Money, Credit, and Banking, May 1993, 25(2), pp. 151-62.

Alesina, Alberto and Tabellini, Guido. "Rules and Discretion with Noncoordinated Monetary and Fiscal Policies.” Economic Inquiry, October 1987, 25(4), pp. 619-30.

Barro, Robert J. "On the Determination of the Public Debt." Journal of Political Economy, October 1979, 87(5, Part 1), pp. 940-71.

Barro, Robert J. and Gordon, David B. "Rules, Discretion and Reputation in a Model of Monetary Policy." Journal of Monetary Economics, July 1983a, 12(1), pp. 101-21.

Barro, Robert J. and Gordon, David B. "A Positive Theory of Monetary Policy in a Natural Rate Model." Journal of Political Economy, August 1983b, 91(4), pp. 589-610.

Becker, Gary S. "A Theory of Competition Among Pressure Groups for Political Influence.” Quarterly Journal of Economics, August 1983, 98(3), pp. 371400 .

Becker, Gary S. "Public Policies, Pressure Groups, and Dead Weight Costs.” Journal of Public Economics, December 1985, 28(3), pp. 329-47.

Becker, Gary S. and Mulligan, Casey B. "Deadweight Costs and the Size of Government." Journal of Law and Economics, October 2003, 46(2), pp. 293-340.

Bordo, Michael D. and Kydland, Finn E. "The Gold Standard as a Commitment Mechanism," in Tamin Bayoumi, Barry Eichengreen, and Mark Taylor, eds., Modern Perspectives on the Classical Gold Standard. Cambridge: Cambridge University Press, 1996, pp. $55-100$.
Campillo, Marta and Miron, Jeffrey A. "Why Does Inflation Differ across Countries?” in Christina D. Romer and David H. Romer, eds., Reducing Inflation: Motivation and Strategy. NBER Studies in Business Cycles. Volume 30. Chicago: University of Chicago Press, 1997.

Chari, V.V.; Christiano, Lawrence and Kehoe, Patrick. "Optimality of the Friedman Rule in Economics with Distorting Taxes." Journal of Monetary Economics, April 1996, 37(2), pp. 203-33.

Click, Reid W. "Seigniorage in a Cross-Section of Countries." Journal of Money, Credit, and Banking, May 1998, 30(2), pp. 154-71.

Correia, Isabel and Teles, Pedro. "Is the Friedman Rule Optimal When Money Is an Intermediate Good?" Journal of Monetary Economics, October 1996, 38(2), pp. 223-44.

Cukierman, Alex. "The Revenue Motive for Monetary Expansion," in Alex Cukierman, ed., Central Bank Strategy, Credibility, and Independence: Theory and Evidence. Chap. 4. Cambridge, MA: MIT Press, 1992.

Cukierman, Alex; Edwards, Sebastian and Tabellini, Guido. "Seigniorage and Political Instability." American Economic Review, June 1992, 82(3), pp. 537-55.

da Costa, Carlos E. and Werning, Ivan. "On the Optimality of the Friedman Rule with Heterogeneous Agents and Non-Linear Income Taxation.” Working paper, MIT, August 2007.

Deane, Phyllis and Cole, W.A. British Economic Growth, 1688-1959: Trends and Structure. Second Edition. Cambridge: Cambridge University Press, 1967.

Dodd, Don. Historical Statistics of the United States. Westport, CT: Greenwood Press, 1973.

Faig, Miquel. "Characterization of the Optimal Tax on Money When It Functions as a Medium of Exchange." Journal of Monetary Economics, July 1988, 22(1), pp. 137-48. 


\section{Han and Mulligan}

Fullerton, Don. "On the Possibility of an Inverse Relationship between Tax Rates and Government Revenues." Journal of Public Economics, October 1982, 19(1), pp. 3-22.

Friedman, Milton. "The Optimum Quantity of Money," in Milton Friedman, ed., The Optimum Quantity of Money and Other Essays. Chicago: Aldine, 1969, pp. 1-50.

Grilli, Vittorio; Masciandaro, Donato and Tabellini, Guido. "Political and Monetary Institutions and Public Financial Policies in the Industrial Countries." Economic Policy, October 1991, 6(2), pp. 342-92.

Grossman, Herschel I. "The Political Economy of War Debt and Inflation," in William S. Haraf and Phillip Cagan, eds., Monetary Policy for a Changing Financial Environment. Chap. 7. Lanham, MD: AEI Press, 1990.

International Monetary Fund. Government Finance Statistics Yearbook. Various issues.

International Monetary Fund. International Financial Statistics Yearbook. Various issues.

Judd, Kenneth L. "Optimal Taxation: Theory and Evidence.” Working paper, Stanford University, 1989.

Kimbrough, Kent P. "The Optimum Quantity of Money Rule in the Theory of Public Finance." Journal of Monetary Economics, November 1986, 18(3), pp. 277-84.

Lucas, Robert E. Jr. and Stokey, Nancy L. “Optimal Fiscal and Monetary Policy in an Economy Without Capital." Journal of Monetary Economics, July 1983, 12(1), pp. 55-93.

Mankiw, N. Gregory. "The Optimal Collection of Seigniorage: Theory and Evidence." Journal of Monetary Economics, 1987, 20(2), pp. 327-41.

McCusker, John J. How Much Is That in Real Money? A Historical Price Index for Use as a Deflator of Money Values in the Economy of the United States. Worcester, MA: American Antiquarian Society, 1992.
Mitchell, B.R. British Historical Statistics. Abstract. Cambridge: Cambridge University Press, 1988.

Mitchell, B.R. International Historical Statistics, Europe: 1750-1993. Cambridge: Cambridge University Press, 1998.

Mulligan, Casey B. and Sala-i-Martin, Xavier X. "Social Security in Theory and Practice (I): Facts and Political Theories." NBER Working Paper No. 7118, National Bureau of Economic Research, May 1999.

Mulligan, Casey B. and Sala-i-Martin, Xavier X. "The Optimum Quantity of Money: Theory and Evidence." Journal of Money, Credit, and Banking, November 1997, 29(4, Part 2), pp. 687-715.

Mulligan, Casey B. and Sala-i-Martin, Xavier X. "Internationally Common Features of Public OldAge Pensions, and Their Implications for Models of the Public Sector." Advances in Economic Analysis and Policy, 2004, 4(1), pp. 1-35.

Palivos, Theodore and Yip, Chong K. "Government Expenditure Financing in an Endogenous Growth Model: A Comparison." Journal of Money, Credit, and Banking, November 1995, 27(4, Part 1), pp. 1159-78.

Phelps, Edmund S. "Inflation in the Theory of Public Finance." Swedish Journal of Economics, March 1973, 75, pp. 67-82.

Poterba, James M. and Rotemberg, Julio J. "Inflation and Taxation with Optimizing Governments." Journal of Money, Credit, and Banking, February 1990, 22(1), pp. 1-18.

Ramsey, Frank. "A Contribution to the Theory of Taxation.” Economic Journal, March 1927, 37, pp. 47-61.

Sargent, Thomas J. "The Ends of Four Big Hyperinflations," in Robert E. Hall, ed., Inflation: Causes and Effects. Chicago: University of Chicago Press, 1982.

Sargent, Thomas J. "Elements of Monetary Reform," in William S. Haraf and Phillip Cagan, eds., Monetary Policy for A Changing Financial 
Environment. Chap. 6. Lanham, MD: AEI Press, 1990.

United Nations. National Accounts Statistics: Main Aggregates and Detailed Tables. Various issues.

Veigh, Carlos A. "Government Spending and Inflationary Finance: A Public Finance Approach." IMF Staff Papers, September 1989, 36(3), pp. 657-77.

Wittman, Donald. The Myth of Democratic Failure: Why Political Institutions Are Efficient. Chicago: University of Chicago Press, 1995.

Woodford, Michael. "The Optimum Quantity of Money," in Benjamin M. Friedman and Frank H. Hahn, eds., Handbook of Monetary Economics. Volume 2. New York: Elsevier Science, 1990, pp. 1067-52. 
